\title{
Sex on Stage: How Does the Audience Know? (Dovizi da Bibbiena, La Calandra, III.10; Shakespeare, Henry V, V.2)
}

\section{What does the theater do (to its audience)?}

Throughout the history of European theatrical poetics the relation between the representation onstage and the audience's perception has been one of its central issues. Questions as to how the audience perceive what is happening on the theater's stage, and how this perception in turn is connected with the techniques and skills applied by the actors, haunt the whole range of theatrical discourse from antiquity onwards. Ever since Plato's and Aristotle's famously contrary opinions on this matter, the medial effects of performance have been at the heart of theatrical disputes; ${ }^{1}$ consequently, they have been linked to basic anthropological and epistemological questions - questions, that is, concerning human ways of perception, of gaining knowledge and understanding, and especially the disruptive and/or enabling effects of representations and emotions in this process. ${ }^{2}$

1 The debate in general is less concerned with possible objections to theatrical texts; since Greek antiquity it has always been the perception of theatrical representation, as well as its effects on audiences and actors, that bothers both the theater's adversaries and its apologists; see Doris Kolesch. "Theater als Sündenschule.” Theaterfeindlichkeit, edited by Stefanie Diekmann, Christopher Wild and Gabriele Brandstetter. Munich: Fink, 2012, pp.19-30, p. 22; Michael Connell. The Idolatrous Eye. Iconoclasm and Theater in Early-Modern England. New York and Oxford: Oxford University Press, 2000, p. 15.

2 Jonas Barish sees anti-theatrical polemics as well as pro-theatrical defences from Plato and Aristotle onwards as part and parcel of more abstract epistemic and anthropological theories, especially with regard to the nexus of (physical) perception, representation and/or mediation, and knowledge. He accordingly integrates Plato's anti-theatrical, as well as Aristotle's pro-

Note: I would like to thank the organizers of the 2015 DramaNet conference Poetics and Politics: Net Structures and Agencies in Early Modern Drama, Toni Bernhart, Jaša Drnovšek, Sven Thorsten Kilian, Joachim Küpper, and Jan Mosch, for the opportunity to discuss an early version of this paper in a particularly productive and friendly atmosphere, and its participants for their inspiring comments and questions. I would also like to express my gratitude to Rudolf Behrens and his team for a productive discussion of an early draft, Jan Söffner for his untiring interest in the ideas here presented, and Stefano Gulizia for an intriguing exchange of thoughts concerning La Calandra. 
The epistemic and anthropological dimensions of these questions touch the very basic problems of Western philosophy: How can human beings know and understand truth? How does imitation and representation (mimesis), or, in fact, any kind of mediation work in this process? ${ }^{3}$ And what is the senses' role in it? Can human beings know without relying on bodily sensations and perceptions? And if all knowledge somehow depends on human sentience, does that mean feelings bring forth their own kind of understanding? Or are they merely getting in the way of the human mind's higher faculties? ${ }^{4}$ The debate centers, therefore, on what today might be summarized as the "question of cognition and embodiment." 5

Seen against this backdrop, it is not even surprising that for centuries philosophers, clergymen, and authors of tracts and pamphlets most carefully scrutinized what happened between actors and their audiences, and, depending on their answers to the abovementioned questions, either became the theater's sworn enemies or its avid defenders. In this age-old controversy, the "characteristic conflict" runs between the position of "a haunting acknowledgement of the potency of the theater," ${ }^{6}$ which - paradoxically - is usually bound up

theatrical position into their wider anthropological framework (Jonas Barish. The Antitheatrical Prejudice. Berkeley, Los Angeles and London: University of California Press, 1981, on Plato see pp. 10 f.; on Aristotle see pp. 28 f. and their episteme see pp. 18, 29). With regard to the Renaissance, Connell states that it is the "alteration of epistemology [...] that powerfully underlies the opposition to the transformed theatre [...].” (Connell, The Idolatrous Eye, p. 17).

3 As Barish notes, since Plato philosophical reflections on drama have been bound up with more general stances towards mimetic or imitational processes: "What is alleged against mimesis in general will apply to the drama with particular force." (Barish, The Antitheatrical Prejudice, p. 5.) For his summary of Plato's and Aristotle's contrary stances towards imitation, see ibid., p. 29. Renaissance concepts of mimesis therefore will play a part in my argument, but for the sake of clarity the discussion of relevant theories has been relegated to the footnotes. 4 Of course, a strong vein of this discourse is engaged in the ethical aspects of the senses' involvement; in particular the moral problem of pleasure derived from sensual perception is one of the most persistent and vexing in this debate. Since I will concentrate on its epistemological side, I will, unfortunately, not be able to do it justice. For a thorough discussion of this aspect of the anti-theatrical discourse, see Connell, The Idolatrous Eye, Chapter 1, "Theater and the Devil's Teats," p. 14-35. For a more general treatment of the problem of aesthetic pleasure in Western thought, see Joachim Küpper. "Uti and frui in Augustine and the Problem of Aesthetic Pleasure in the Western tradition (Cervantes, Kant, Marx, Freud).” MLN, no. 127, 2012, pp. 126-155.

5 William N. West. "Understanding in the Elizabethan Theatres.” Renaissance Drama, no. 35, 2006, pp. 113-143, p. 126.

6 Barish, The Antitheatrical Prejudice, p. 5. As Stefanie Diekmann remarks, to its enemies the theater "was not nothing" - it was "too much" (Stefanie Diekmann. "Kein Theater für Genf. Rousseaus Brief an d'Alembert." Theaterfeindlichkeit, pp. 31-40, p. 38; my translation). 
with "an all the more stinging repudiation of it"7 on the one hand, and the claim of the theater's educational usefulness on the other hand, which is equally paradoxically - usually linked to a belittling of its aesthetic impact. ${ }^{8}$ The theater's opponents credit the theater with a massive (and hugely dangerous) impact on spectators' (and also actors') lives, precisely because according to their view people usually do not perceive what is referred to by the dramatic action, and instead they are directly bodily affected by the presence of the actors' bodies. ${ }^{9}$ What is more: According to the anti-theatrical discourse, the audience will learn nothing good from attending theatrical events. With the theater's illusory presentation of characters and events, it is ill qualified to impart any form of truth. ${ }^{10}$ The theater's supporters, in contrast, generally assume that spectators do follow the represented story, that they do understand and learn any moral and religious lessons it may impart, and that the affection of their senses - attenuated by their consciousness that what they see on stage is not happening "for real" - simply helps to make the plays' messages more impressive. ${ }^{11}$

7 Barish, The Antitheatrical Prejudice, p. 5. The fact that the polemics become more acrimonious the more the theater's enemies regard it as a "strong medium" indicates an "ambivalent affective investment" on their part (Stefanie Diekmann, Christopher Wild and Gabriele Brandstetter. "Theaterfeindlichkeit. Anmerkungen zu einem unterschätzten Phänomen.” Theaterfeindlichkeit, pp. 7-15, p. 9; my translation).

8 Barish, The Antitheatrical Prejudice, p. 29.

9 John Rainolde's anti-theatrical treatise Th'overthrow of stage-playes (Middleburgh, 1599, quoted here from the facsimile edition New York: Garland Publishing, 1974) raises strong objections even against morally flawless plays, because members of the audience might still be more attracted to the actors - rather than the characters they represent - especially when young men play female parts: "And what if all, who were present [...] did admire the constancie of Penelope? Could no evill affection bee therefore stirred in anie by seeing a boy play so chast a part?" (p. 111). Particularly the representation of emotions by a "stage-player" will, due to his physical presence, provoke real ones in the audience - "[...] an effeminate stage-player, while hee faineth love, [...] imprinteth wounds of love” (p. 18) - and this effect occurs, in Rainolde's view, totally independent of the represented character, or the play it appears in.

10 According to anti-theatrical positions the illusion the theater provides will automatically taint every object of theatrical representation with "falsehood," even biblical and mystical contents. Also, a medium that consists of deceit could teach its audience nothing but deception and fraud itself. Hence, the opposition to religious drama was, if possible, even more violent than that to other dramatic forms and genres (Barish, The Antitheatrical Prejudice, p. 77; Connell, The Idolatrous Eye, p. 28-29).

11 Thomas Heywood (1570s-1641), himself an author and playwright for the Elizabethan and Jacobean stage, claims drama to be more apt to "moove the spirits of the beholder to admiration" (p. 20) than other forms of mimetic art (such as painting or literature), and admits the theater's powerful emotional effects on its audience - "it hath power to new-mold the harts of the spectators, and fashion them to the shape of any noble and notable attempt" (p. 21) - but 
It is also no surprise that pro- and anti-theatrical polemics often flared up in times of flourishing theatrical production. ${ }^{12}$ But the same could be said vice versa: Especially in the sixteenth and seventeenth centuries, when the theater found itself at the center of reformation as well as counter-reformation cultural policy, ${ }^{13}$ the hot-tempered debates and violent attacks on it did not necessarily

the cause is, according to Heywood, always the audience's enthusiasm for the impressively represented characters, rather than the physically present actors: “[...] what English blood, seeing the person of any bold Englishman presented, and doth not hugge his fame, pursuing him in his enterprise with his best wishes [...] as if the personator were the man personated?" (p. 21). Heywood claims therefore that "action was the neerest way to plant understanding in the hearts of the ignorant" (p. 27). See Thomas Heywood. "An Apology for Actors in Three Books (1612)." Publications of the Shakespeare Society of London, vol. 6: Thomas Heywood: Dramatic Works, Nendeln (Liechtenstein): Kraus Reprint LTD, 1966, without continuous pagination.

12 Barish, The Antitheatrical Prejudice, p. 66; see also Connell, The Idolatrous Eye, p. 15, for detailed examples.

13 The Protestants' and Puritans' strong scepticism (or rather: their fear, loathing, and disgust), and the more lenient position of Catholics towards the theatrical dimension of embodiment are seen in connection with the issue of their contrary answers to the question "what sort of understanding is necessary for salvation," i.e. whether liturgical practices and rituals "needed to be intellectually understood or merely corporeally performed" (West, "Understanding in the Elizabethan Theatres," p. 118). With their pro- and anti-theatrical positions, therefore, treatises also negotiated the most fundamental cultural and religious issues (Barish, The Antitheatrical Prejudice, p. 76), and it is no surprise that anti- and pro-theatrical controversies erupted with particular violence in countries strongly affected by the Reformation. Yet, not all Protestant writers were the theater's enemies (during the reign of Henry VIII plays were even seen as an appropriate means for promoting the Protestant cause, see Connell, The Idolatrous Eye, p. 21) - and not all Catholic writers were its friends, as the example of Carlo Borromeo, cardinal-archbishop of Milan in 1565-1584, demonstrates (see ibid., p. 30).

In Italy the debate was certainly less violent, and strong anti-theatrical positions are rarely found (as, by the way, is related research). Nevertheless, the theater's effects on audiences were a cause of concern, which found expression in various attempts at its purification, mostly by incorporating a restrictive view of theatrical production, especially comedy, into the genre's poetics. One striking example of Italian anti-theatricality in the shape of theatrical poetics is Pino da Cagli's Breve considerazione intorno al componimento de la Comedia de' nostri tempi (in: Trattati di poetica e retorica del Cinquecento, 4 vols., edited by Bernard Weinberg. Rome and Bari: Laterza, 1970-1974, vol. 2, p. 429-629), as Pino wanted to see theater reduced to delivering - and listening to - speeches (see Richard Andrews. Scripts and Scenarios. The Performance of Comedy in Renaissance Italy. Cambridge et al.: Cambridge University Press, 1993, p. 210 f.). Various Italian examples of anti-theatrical treatises, beginning with Carlo Borromeo's invectives, are published in Ferdinando Taviani. La fascinazione del teatro. Rome: Bulzoni, 1969, Parte Seconda: "Storia e documenti," p. 3-285. For an overview of the debate in Italy, see Claudio Bernardi. "Censura e promozione del teatro nella Controriforma." La nascita del teatro moderno, Cinquecento-Seicento, edited by Roberto Alonge and Guido Davico Bonino. Turin: Einaudi, 2007 (Storia del teatro moderno e contemporaneo, 1), pp. 1023-1042. 
inhibit theatrical production. They also triggered, on the part of playwrights and players, a heightened self-consciousness of the "power of their medium" as well as a new awareness of theatrical "modes of representation" and the theater's "phenomenology." ${ }^{4}$ I will suggest therefore, with Michael Connell, that early modern drama "assumed something of the character it did, not in spite of, but because of, the attack upon it."15 Long before the anti-theatrical polemics reached the peak of their influence on theatrical practices with the famous ban on play-staging in mid-seventeenth-century England, practitioners simply could not help but take a stance vis-à-vis the diverse charges leveled against the stage. ${ }^{16}$

This paper will compare two plays, Dovizi da Bibbiena's La Calandra (1513) and Shakespeare's Henry $V$ (1599), with regard to the stance they take towards this controversy: It will start out from the observation that even though neither play explicitly reflects upon the controversy's main questions, both plays provide answers to them by shaping the audience's perception in specific (and

14 Connell, The Idolatrous Eye, p. 18.

15 Ibid. The anti-theatrical polemic in some sense created and reinforced "[the theater's] power in the very act of attempting to demonize it" (ibid.). Therefore, the relation between the theater's enemies and the theater itself can be understood as "symbiotic and productive" (Diekmann, Wild, Brandstetter, “Theaterfeindlichkeit,” p. 8; my translation).

16 For the ban on plays from 1642 to 1660, ordered by Parliament during the English Civil War and the Interregnum, see English professional theatre. 1530-1660, edited by G. W. Gladstone Wickham, H. Berry and W. Ingram. Cambridge and New York: Cambridge University Press, 2000. Even before this drastic example of the influence of the controversy on theatrical practice, playwrights negotiated its fundamental issues sometimes more, sometimes less explicitly. Ben Jonson's case is particularly apt to illustrate the often intricate relations of secret alliances and mutual fascination between attack and defence in the controversy, since Connell notes from the outset that Jonson - "in his own allegiance with humanist culture" (Connell, The Idolatrous Eye, p. 12) - often "seems half in agreement with [the Puritans'] critique of visual spectacle," and therefore describes his own plays as "poetry," highlighting their textuality (ibid., p. 13; see also Barish, The Antitheatrical Prejudice, Chapter V: "Jonson and the Loathèd Stage,” p. 132-154). In various instances Jonson also insists that a true understanding of his plays is only available to readers, not to audiences (West, "Understanding in the Elizabethan Theatres,” p. $120 \mathrm{ff}$.). One Shakespearean example of conscious appropriation of anti-theatrical positions within a play is, as Björn Quiring's analysis convincingly shows, Othello and its obsession with the emotional and physical effects of deception brought about by theatrical means (Björn Quiring. “'Men should be that they seem.' Antitheatralität in Shakespeares Othello." Theaterfeindlichkeit, pp. 73-85). Connell reads Hamlet in a similar vein, seeing the play's emphasis on the deceptiveness of the visual sense, and its constant concern with a possible hiatus between inward emotional state and outward appearance, as reflecting the strong iconoclastic streak of early modern anti-theatrical discourse (Connell, The Idolatrous Eye, p. 132 ff.). 
contrary) ways, and by creating particular relationships between audience and onstage action; with this, each play also negotiates the underlying problem of cognition and embodiment.

So, contrary to the promise of its title, this paper is not - or not mainly concerned with sex. Bluntly put, it is concerned with the question how two particular plays implement ways to make the audience know. This paper is, however, in so far concerned with sex, as these questions touching the mediality of theatrical performance seem to become particularly visible in two scenes that represent sexual relations: in Scene III.10 of Dovizi da Bibbiena's La Calan$d r a$, and V.2 of Shakespeare's Henry $V$. In fact, this paper will try to show that one of these scenes' main objectives is to fashion the audience's stance and perception, and, thus, to produce (or at least to highlight) precisely the kind of media effects - and the kind of knowing - that each play relies on: In the case of La Calandra, this paper will argue, the audience's perception is guided towards an uninvolved, detached, and superior observation of the fictional world of the play; thus, the play seems to want to highlight the fact that the audience will, firstly, know and understand something about this world, and that they will, secondly, know and understand its fictional character. In the case of Henry $V$, instead, the scene seems to guide the audience towards a perception and an understanding of the action that is based on their emotional and embodied taking part in it. Rather than being shown something about a closed off and therefore analyzable world of make-believe, spectators are drawn into what today's phenomenology of embodied experiences describes as "participatory sense-making."17

This means that within the complex field of Renaissance theories of human perception and epistemology, both plays, and in particular the two scenes upon which this paper focuses, can be identified with different, even oppositional views; views, however, which so far have not received an equal share of researchers' attention. La Calandra provides and requires a way of understanding on the part of the audience that has long been at the center of much of the theoretical and philosophical research on Renaissance episteme, and therefore seems rather familiar. It is firmly grounded in the emerging concept of knowledge as a mental representation derived from - as well as further submitted to - analysis, that is: hermeneutic and/or semantic explanation, discussion,

17 Hanne De Jaegher and Ezequiel Di Paolo. "Participatory Sense-Making: An Enactive Approach to Social Cognition.” Phenomenology and the Cognitive Sciences, no. 6, 2007, pp. 485507 , see also section $\mathrm{V}$ of the present essay. For an overview of related phenomenological theories see Evan Thompson and Mog Stapleton. "Making Sense of Sense-Making. Reflections on Enactive and Extended Mind Theories.” Topoi, no. 28, 2009, 23-30. 
contestation, or comparison. ${ }^{18}$ Henry $V$ and its wooing scene, on the contrary, draws on a way of understanding that for a long time Western philosophy did not regard as knowledge at all. It is only thanks to recent research in phenomenology and neuroscience on the embodied, enactive, embedded, and extended mind ${ }^{19}$ that situated cognition has been awarded the status of being - indeed knowledge; ${ }^{20}$ and even more recently cultural studies have come to recognize

18 This strand of Renaissance - mostly Neoplatonic - accounts of the processes of knowledgeacquisition often uses the metaphor of "printing" to describe the reception of knowledge into the human brain, or the "rational soul" located there (Miranda Anderson. The Renaissance Extended Mind. Basingstoke: Palgrave Macmillan, 2015, quotes Bacon's [p. 82], Coeffeteau's [p. 89-90], Crooke's [p. 113], and Ficino's [p. 113] theories of the soul and its diverse parts, their locations, and abilities). The specifically human capability of gaining knowledge by reflection and learning was either conceived of as a form of remembering the "universal forms imprinted in human minds, understanding of which is filtered through sensory impressions" (ibid., p. 82), or as a process during which the brain's "substance" can "reveiue the impression of other things" (see Helkiah Crooke. Mikrokosmographia. A Description of the Body of Man. London, 1615, p. 455, as quoted by Anderson, The Renaissance Extended Mind, p. 113). Even though researchers in Germany have often taken a different angle on Renaissance episteme - focusing not on ways of gaining knowledge, but rather on the objects of knowledge and their processing - their findings in this case complement Anderson's examples: according to Andreas Kablitz and Gerhard Regn, who refer to earlier works by Klaus W. Hempfer, the "dominant epistemological habitus of the time" links the "constitution of knowledge" to the "interpretation of texts" (Andreas Kablitz and Gerhard Regn. "Vorwort." Renaissance - Episteme und Agon, edited by iid. Heidelberg: Winter, 2006, pp. 7-9, p. 7; my translations; see Klaus W. Hempfer. "Die Konstitution autonomer Vernunft von der Renaissance zur Aufklärung.” Grundlagen der politischen Kultur des Westens. Ringvorlesung an der Freien Universität Berlin, edited by id. and Alexander Schwan. Berlin and New York: de Gruyter, 1987, pp. 95-115). Since in the Renaissance the corpus of texts is - compared to medieval times - considerably widened, this motivates the "development of a new hermeneutic consciousness" (ibid., p. 7), that is, the further contestation and discussion of knowledge, e.g. in the literary form of the dialogue (see Klaus W. Hempfer. "Probleme traditioneller Bestimmungen des Renaissancebegriffs und die epistemologische 'Wende'." Renaissance. Diskursstrukturen und epistemologische Voraussetzungen: Literatur - Philosophie - Bildende Kunst, edited by id. Stuttgart: Steiner, 1991, pp. 9-45).

19 Even though the four terms stress different key aspects, they all express the view that cognition is body-based and neither restricted to a closed-off and solitary brain nor entirely based on processes of mental representation, and therefore "challenge the standard model that views the body and the world as peripheral to understanding the nature of cognition." (Anderson, The Renaissance Extended Mind, p. viii). They are now frequently summarized as the "4E perspective" in order to emphasize their common ground (see e.g. ibid., p. viii). It would exceed the purpose of this paper to elaborate the internal differences and ongoing debates in this field: for an overview of the most important strands of research in this context see Anderson's excellent introductory chapter, "The Extended Mind," pp. 1-40.

20 See e.g.: Antonio Damasio. Descartes' Error. Emotion, Reason and the Human Brain. London: Vintage Books, 2006 [1994]; Mark Johnson. The Meaning of the Body - Aesthetics of Human Understanding. Chicago and London: University of Chicago Press, 2007; George Lakoff 
the importance of concepts of embodied and extended understanding in Renaissance thought. ${ }^{21}$ As Miranda Anderson notes: “[T]he Renaissance displays an especially marked consciousness, concern and celebration about human cognitive extendedness" and stresses the "belief that humans had porous brains and bodies" so that "external resources could play fundamental roles in their cognitive processes." 22

The circumstance that the two different plays belong to two different cultural-political settings, and also to two different theatrical traditions each with their own, specific conditions of performance, will be seen as generally supporting the different perceptional stances, and the different ways of making the audience know, enforced by the plays. But, seen against the backdrop of their specific performative conditions, it becomes particularly clear that the plays do not simply affirm one specific mode of perception; in fact, I also intend to show how far they contest the trustworthiness of their respective perceptional stances and counterpoise them to the other way of knowing, and to a certain extent - show their inseparability. With this, I hope to show from the example of two very specific, microscopic instances how Renaissance drama not only negotiates questions of knowledge and its relation to bodily perceptions and emotions, but also voices the related cultural anxieties - or excitement.

Even though my interest is the audience's perception and knowledge, I do not intend to analyze this with regard to a particular production of each of the

and Mark Johnson. Philosophy in the Flesh - the Embodied Mind and its Challenge to Western Thought. New York: Basic Books, 1999; P. Robbins and M. Aydede (eds.). The Cambridge Handbook of Situated Cognition. Cambridge and New York: Cambridge University Press, 2009; Larry Shapiro. Embodied Cognition. London and New York: Routledge, 2011; Zdravko Radman (ed.). Knowing Without Thinking. Mind, Action, Cognition and the Phenomenon of the Background. Basingstoke and New York: Palgrave Macmillan, 2012.

21 Apart from Anderson's ground-breaking study, which offers an overview of Renaissance concepts of embodied and enactive cognition, and West's analysis of the diverse notions of intellectual and corporeal understanding - and their interrelation - in Elizabethan and Jacobean theater, see also Michael Emily. "Renaissance Theories of Body, Soul and Mind." Psyche and Soma. Physicians and Metaphysicians and the Mind-Body Problem from Antiquity to Enlightenment, edited by John P. Wright and Paul Potter. Oxford: Clarendon Press, 2000, pp. 147-172; Environment and Embodiment in Early Modern England, edited by Mary Floyd-Wilson and Garrett A. Sullivan. Basingstoke: Palgrave Macmillan, 2007; with regard to Elizabethan theatrical practices and their relation to concepts of cognitive extendedness and embeddedness, see Evelyn Tribble. "Distributing Cognition in the Globe." Shakespeare Quarterly, no. 56, 2005, pp. 135-55 and ead. Cognition in the Globe: Attention and Memory in Shakespeare's Theatre. Basingstoke: Palgrave Macmillan, 2011.

22 Anderson, The Renaissance Extended Mind, p. ix. 
plays. In comparison with Stefano Gulizia's contribution to this volume, which provides a close reading of the fascinating description Baldassare Castiglione gives of his own production of La Calandra in 1513 Urbino, and in particular the effects its elaborate material arrangement and the interior design of the theatrical space had on its audience, this paper is limited to a more generic approach regarding the contemporary conditions of performance. Nevertheless I would like to see it as to a certain extent complementing Gulizia's microhistorical perspective - my intention is, like Gulizia's (whose phrase I am borrowing here), to look at "what the scenes do, more than at what they mean."23

\section{II (Making sense of) senseless scenes}

Apart from the common motif of their representation - sex - the two scenes on which this paper focuses share another, and perhaps even more important, feature: Neither of them continues their respective play's action; they have no structural function in its intrigue. In the case of Scene III.10 of La Calandra, the complicated action of this exemplary commedia erudita remains suspended for the duration of a short intermezzo between two servants, which has no consequences whatsoever on the further development of the play's intricate plot, which evolves around a pair of twins. Scene V.2 of Henry V, known as the "wooing scene," is, from a structural point of view, equally superfluous: The main action, centering around the greatest military victory in all English history, the Battle of Agincourt, and its protagonist Henry of Monmouth, has already reached its conclusion. The French have surrendered, and Catherine de Valois, the French princess, will have to marry Henry whether she likes it or not.

It appears to be as a consequence of this senselessness, that researchers in literary, cultural, or drama studies have, in both cases, not yet come to terms with these scenes. In the case of La Calandra's striking display of licentiousness on the part of the servants, scholars seem to have silently agreed to ignore it, possibly because - from a researcher's point of view - the scene causes too

23 See Stefano Gulizia. "Castiglione’s Green Sense of Theater.” With respect to Henry V, I will occasionally refer to recent productions for screen and stage; unfortunately this will not be possible for La Calandra due to a lack of available productions. Giorgio Padoan mentiones several theatrical productions of La Calandra in the 1970s ("Introduzione." La Calandra: Commedia elegantissima per messer Bernardo Dovizi da Bibbiena, edited by Giorgio Padoan. Padua: Editrice Antenore, 1985, pp. 1-34, p. 6), as does Mario Baratto. La commedia del Cinquecento. Vicenza: Neri Pozza, 1975, p. 14 ff., but unfortunately none of them are available on video/DVD. 
few and too many problems at the same time. Its crude straightforwardness leaves little room for critical interpretation at the level of the textual surface, and at the level of structure its redundancy challenges the classical unity of action - that is: the poetical precept that the commedie erudite were virtually obsessed with. ${ }^{24}$ Compared to sexual encounters in other comedies, this one is extraordinary, and also problematic, because it is casual. ${ }^{25}$ Why the scene was even included in the play is a question that still remains to be asked. The wooing scene at the end of Henry $V$ has obviously been the object of more detailed scholarly attention. ${ }^{26}$ But, even though in this case much ink has been spilled, the purpose and function of this "minicomedy" 27 within the context of a history play that is, after all, mainly concerned with war, remains strangely obscure. Today the main branch of criticism reads it as basically a chauvinistic and/or nationalistic humiliation of the French princess and, by extension, the French people, as well as a crude (and somewhat superfluous) affirmation of the king's male and/or English identity. ${ }^{28}$

24 For the emergence of the Italian commedia erudita as a conscious imitation/emulation of the classical Roman comedy, and its faithful reliance on the classical poetical unities, see D. Radcliff Umstead. The Birth of Modern Comedy in Renaissance Italy. Chicago and London: University of Chicago Press, 1969.

25 It is not unusual for early Italian comedies to include sex between their pairs of young lovers. In other examples of early comedies, however, like Ariosto's La Lena and I Suppositi, and - of course - Machiavelli's La Mandragola, these encounters always happen offstage and are then reported to other characters as well as to the audience via the classical technique of teichoscopy. More importantly, in other comedies sex is always crucial to the respective play's plot, as its happy ending routinely legitimizes the lovers' pre-existing relationship.

26 Or rather, as Goldman put it, it looks back on "a long tradition of solemn critical disapproval” (Michael Goldman. The Energies of Drama. Princeton: Princeton University Press, 1972, p. 72).

27 Donald Hedrick. “Advantage, Affect, History, Henry V.” PMLA, no. 118, 2003, pp. 470-487, p. 470.

28 See e.g.: Karen Newman. "Englishing the Other: 'Le tiers exclu' and Shakespeare's Henry V." Fashioning Femininity and English Renaissance Drama, edited by ead. Chicago: University of Chicago Press, 1991, pp. 95-108; Helen Ostovich. “'Teach You Our Princess English?’ Equivocal Translation of the French in Henry V." Gender Rhetorics: Postures of Dominance and Submission in History, edited by Richard C. Trexler. Binghamton: Center for Medieval and Early Renaissance Studies, 1994 (Medieval and Renaissance Text and Studies), pp. 147-161; Philip Seargeant. "Ideologies of English in Shakespeare's Henry V." Language and Literature, no. 18, 2009, pp. 25-44; Grace Tiffany. "Being English Through Speaking English: Shakespeare and Early Modern Anti-Gallicism.” Word and Rite: The Bible and Ceremony in Selected Shakesperean Works, edited by Beatrice Batson. Newcastle-upon-Tyne: Cambridge Scholars Publishing, 2010, and Alison Walls. "French Speech as Dramatic Action in Shakespeare's Henry V." Language and Literature, no. 22, 2013, pp. 119-131. Apart from the sometimes obvious anachronisms of this perspective, the simple historical fact that the Tudor monarchs descended in a direct line from the historical Catherine of Valois (and her second husband Owen Tudor) provides the 
I will argue here that it is in these senseless scenes that each of the plays shapes and fashions the perception of the audience. That is, whatever the plays presuppose the theater can do is exacerbated in these scenes: the senseless scenes may be senseless only with respect to the plays' plots - in performance, this paper will show, their sense coincides with their effect on the audience's perception. It is no coincidence, then, if both in La Calandra and in Henry $V$ the senseless scenes are also the most sensual. ${ }^{29}$ If, as I will argue here, it is the purpose of both scenes to shape the spectators' experiences, it is no surprise that the scenes intensify the experiencing. ${ }^{30}$

\section{La Calandra: who knows what?}

Dovizi da Bibbiena's early play, staged for the first time in 1513 as part of a series of court festivities in Urbino, ${ }^{31}$ is not only one of the most successful Italian comedies of the sixteenth century, ${ }^{32}$ it is also one of the most complicated. Luckily, the details of the several amorous intrecci - mistaken identities, sexual crossdressing, and adultery included - are not of great importance for this paper's argument. At the center of the comic confusion is a motif obviously

most convincing argument against this interpretation. Stephanie Downes. "French Feeling: Language, Sex and Identity in Henry V." Shakespeare and Emotions. Inheritances, Enactments, Legacies, edited by Robert S. White. Basingstoke and New York: Palgrave Macmillan, 2015, pp. 59-68, instead reads the scene as an example of complex, non-pejorative, and ambivalent negotiations of "emotional expression and cross-linguistic communication" (ibid., p. 66). I will refer to her observations further on.

29 Thanks are due, and gladly given, to Stephen Nichols (Baltimore), who brought this connection between senselessness and sensuality in both scenes to my attention.

30 For the further development of my argument it is essential to view both plays as dramatic works intended for performance (that is: not intended for silent scholarly reading), and in agreement with much of the recent research on English Renaissance drama I will assume that performance constitutes much of their meaning and artistic potential.

31 Apart from Stefano Gulizia's contribution to this volume, see A. Fontes-Baratto. "Les fêtes à Urbin en 1513 et la Calandria de Bernardo D. da Bibbiena." Les écrivains et le pouvoir en Italie à l'époque de la Renaissance (serie II), edited by André Rochon. Paris: Université de la Sorbonne Nouvelle, 1974, pp. 45-80; Franco Ruffini. "Analisi contestuale della Calandria nella rappresentazione urbinate del 1513." Biblioteca teatrale, nos. 15/16, 1978, 70-139, and Commedia e festa nel Rinascimento. La Calandria alla corte di Urbino. Bologna: Il Mulino, 1986.

32 Pamela D. Stewart. “A Play on Doubles. The Calandria Play.” Modern Language Studies, no. 14, 1984, pp. 22-32, p. 22; Stefano Gulizia. "Spatial traffic. Cognitive ecologies of Bibbiena's Calandra." Studi rinascimentali, no. 9, 2011, pp. 115-127, p. 117; but mostly G. L. Moncallero. "La fortuna della Calandria nel Cinquecento." Aevum, no. 42, 1968, pp. 100-103. 
taken over from Plautus' Menaechmi, ${ }^{33}$ namely a pair of twins, Lidio and Santilla, who were separated as infants and who have each independently come to Rome to look for their respective sibling, only to find themselves involved in intertwined love stories in the course of which they each take on their sibling's identity and gender: Lidio falls in love with the rich lady Fulvia; in order to deceive her husband Calandro ("lo sciocco per antonomasia"34 and the predestined victim of the comic beffa), he goes to their rendezvous dressed as a woman, which then causes the betrayed husband - of all people! - to fall in love with him. In the meantime Santilla (or "Lidio femina," as stage directions call her) faces a most inconvenient marriage proposal: her master Petrillo, who does not know her true gender, wants her to marry his daughter. This complicated situation brings forth a whole range of confusing coincidences and false identifications, a number of which are mediated by a charlatan sorcerer named Ruffo, who pretends to be able to change a person's gender, only to be surprised at what he sees as his own success. Needless to say, it all ends well - in the way Italian comedies sometimes end well: the twins meet, and eventually recognize, each other, they revert back to their true identities and genders, they each find a conveniently rich spouse, and Lidio, though guilty, is saved from the accusation of adultery.

Research has successfully shown that La Calandra is - maybe more than any other play belonging to the commedia erudita tradition - based on a strict division of the theatrical space into two distinct compartments, each of which is, for the duration of the play's intrigue, inhabited by a specific group of characters who are only aware of a limited part of the play's intrafictional reality. ${ }^{35}$ Pamela Stewart has convincingly described the effects this has on the characters: two neatly separated groups form around the two twins; ${ }^{36}$ the members of each group only know one twin's background story and this shapes their actions as well as their perception of the unfolding events. With the comic confusion in full swing, characters repeatedly express their own lack of understanding of what is going on around them. ${ }^{37}$ Little by little the members of the two groups do get into contact with members of the other group, and this

33 See Padoan, “Introduzione,” p. 158.

34 Pamela D. Stewart. "Il testo teatrale e la questione del doppio destinatario: l'esempio della Calandria.” Quaderni d'italianistica, no. 1, 1980, pp. 15-29, p. 17.

35 Ibid., p. $16 \mathrm{f}$. Note especially the diagram showing the distribution of knowledge between the characters of the play on p. 17.

36 Ibid., p. 16.

37 See Fessenio in IV.6 or Samia in V.1. I will refer to the play's text according to the edition by Padoan; references in brackets are to this edition. 
eventually leads to their acknowledgement of the respective other half of the play's reality, and, finally, to the reunion of the twins and the solution of the various intrecci. Essentially, though, even the obligatory lieto fine is based on this division of knowledge, and on its effect of excluding some characters from the whole truth even at the play's conclusion. ${ }^{38}$ That is, the twins' luck and fortune builds on the fact that neither Lidio's future father-in-law, nor Fulvia's stupid husband, nor their future spouses will ever be aware of the whole truth. ${ }^{39}$ This division of knowledge is implemented and reflected, according to Giulio Ferroni's reading, by the comedy's initial "compartizione economica dello spazio" and its overcoming as the comedy unwinds. ${ }^{40}$ The characters' limitation of knowledge is mirrored by their spatial confinement: the members of the two groups initially inhabit two separate areas of the stage, with Fulvia's and Calandro's house as the center of one, and Petrillo's house at the center of the other, and their growing recognition is strongly linked to the dissolution of this spatial segregation. ${ }^{41}$

Ultimately, the division of the theatrical space in La Calandra and the division of knowledge among its characters appear congruent, to the extent that the different areas of action can be identified as spaces of knowledge: the play not only displays the limitations of the characters' insight into the play's action as limits upon spatial movement and overview, but also highlights the fact that a certain point of view on the comical events is - literally - caused by the observer's perspective and therefore coincides with a certain physical position in space. ${ }^{42}$ As Stefano Gulizia rightly notes, in La Calandra insight depends directly on "spatial traffic," that is: physical position and movement in space. ${ }^{43}$

38 Giulio Ferroni. "I due gemelli greci a Roma: il doppio e la scena nella Calandria del Bibbiena.” Studi romani, no. 28, 1980, 23-33, p. 32.

39 “[...] essi non conoscono e non vengono mai a conoscere né l'una né l'altra parte della verità, [...]." Stewart, "Il testo teatrale,” p. 17; see Ferroni, "I due gemelli,” p. 32.

40 Ibid.

41 Lidio and Santilla “[...] si impadroniscono dello spazio della scena romana come spazio del radoppiamento [...].” (ibid., p. 31). As is typical of this genre, this doubling of the twins' action-space is in turn confirmed by a doubling of their economic wealth, see ibid., p. 32; with regard to the complementarity of spatial and economic possibilities of action in the commedia erudita, see Rudolf Behrens and Esther Schomacher. "Semantische Subversionen städtischen und häuslichen Raums in der Komödie des Cinquecento.” Raum-Erkundungen. Einblicke und Ausblicke, edited by Elisabeth Tiller and Christoph Mayer. Heidelberg: Winter, 2011, pp. 89124, p. 113-117.

42 Stewart sees this as part of the play's "giuoco fra i vari destinatari e le varie prospettive dalle quali questi consideranno gli avvenimenti," see Stewart, "Il testo teatrale," p. 15.

43 Gulizia, “Spatial Traffic,” p. 127. 
For the play's spectators this direct link between spatial position or movement and knowledge has strong - and not wholly unpleasant - implications. To them, the coincidence of spatial position and availability of knowledge applies in a particular way: in La Calandra it is the audience alone who find themselves in the position of observing the action onstage from the outside. Therefore, the spectators - "divinely amused and omniscient" 44 - are able to identify the limitations of each character's individual perspectives on what happens, as well as to integrate the characters' limited knowledge into the bigger picture of the play's entire action. ${ }^{45}$ If other commedie erudite incorporate the position of strategic overview into their cast of characters - usually in the shape of a savvy servant who pulls the strings of the comic intrecci ${ }^{46}$ mirroring, as it were, the audience's overview from inside the fictional world, La Calandra, quite uniquely and remarkably, does not. As Stewart remarks laconically: "It would be difficult to find a scene which does not presuppose a difference in the levels of information between characters and audience." 47 As I will try to show, in Scene III.10 this is taken to the extreme: here the space of the theater is strictly hierarchized into several spaces, which in turn coincide with different areas of knowledge about the action. At the same time the knowledge of the audience is extended to a heightened awareness of the fictional quality of the performance.

Within the context of the play the servants' amorous tête-a-tête is introduced by a little soliloquy by the serva Samia, in the course of which she expresses her support and sympathy for her mistress Fulvia, who had, in a previous scene, abandoned all sense of propriety and gone off, dressed as a man, to see her lover Lidio. Samia declares without much further ado that she will now do the same and see her lover Lusco, and promptly disappears into Fulvia's house, locking the door. Shortly afterwards another servant, Fessenio, arrives and requires access to the very same house. What is happening in III.10,

44 "olimpicamente divertito e onnisciente", Stewart, "Il testo teatrale," p. 16.

45 "Durante tutto lo svolgimento della commedia nessuno dei personaggi riesce a capire interamente quello che sta accadendo: soltanto il pubblico è al corrente di tutta la verità.” (Ibid.)

46 The best-known example of this would be the character of Ligurio in Niccolò Machiavelli's La Mandragola, see Angela Guidotti. "Una perfetta macchina drammaturgica: La Mandragola." Il modello e la trasgressione: commedie del primo '500, edited by ead. Rome: Bulzoni, 1983, pp. 61-101.

47 "Sarebbe difficile trovare una scena che non presupponga un diverso livello di informazione fra personaggi e spettatori." (Stewart, "Il testo teatrale,” p. 16) In La Calandra, spectators are aware of both of the twins' true identities and genders and their tactics of cross-dressing from the "Argumento" onwards (s. La Calandra, p. 65-66); they would also be the only ones to comprehend the real causes of Ruffo's supposed magic. 
then, is as simple as it is graphic: two servants (Samia and Lusco) have sex inside the house of Samia's mistress, while another servant (Fessenio) tries to enter the house from the outside. The short dialogue of the scene links the servant's desire to enter the house to what is going on inside it: On finding the entrance locked, Fessenio, on the outside, gives instructions as how to open it. Samia, on the inside - obviously giving an excuse for not opening the door keeps telling him that she is trying to unlock the door but failing because the key does not work. After a while, with Fessenio on the outside getting more and more impatient, the door opens and the action resumes its vertiginous pace. An audience, though, informed of Samia's intentions and therefore in the know about what is happening behind the closed door, will unmistakeably decode her descriptions of the action indoors - such as "putting the key in the lock" ("metter la chiave nella toppa," III.10.167), "shaking” or "rattling” the key ("Scuoto quant'io posso," III.10.177), or "oiling” it ("ho tutta unta la chiave,” III.10.179) - as unequivocal, and actually rather coarse metaphors for the servants' erotic encounter.

In this way, the difference in knowledge on the part of the audience and the characters involved (especially Fessenio) becomes the very foundation of the scene's lewd comicalness: The fact that the audience know better what is going on behind the closed door than Fessenio in front of the door does, is the reason why the audience can (correctly) interpret Samia's comments from the inside as bawdy metaphors, while, as the audience also observes, Fessenio (wrongly) takes them literally. If the play is - in its very structure - based on the audience's advantage of information, here this theatrical ploy is played out to its fullest comic potential, and, as such, is brought to the fore: the audience is obviously not only supposed to chuckle about Samia's and Lucio's cleverly concealed rendezvous, but also about Fessenio's total ignorance and naïveté, and the striking, comical contrast between the character's limited insight and their own unlimited knowledge regarding the theatrical world.

According to Stewart it takes the final solution of the comic intrecci to bring at least some of the characters level with the audience. After the twins' proper identification, Stewart sees Lidio and Santilla, their servants, and Fulvia in the same position of complete understanding that the audience has occupied all along. ${ }^{48}$ A closer look at Scene III.10 reveals this to be only partly true: the scene, it seems, not only emphasizes and visualizes the segregation of the theatrical spaces and the different levels of knowledge distributed among characters and spectators - its outright farcical character also highlights its fictiona-

48 Stewart, “Il testo teatrale,” p. 18. 
lity. After all, through all its sexual hilariousness the scene is positively exhibiting its own status of make-believe. The graphic bawdiness of Samia's metaphors seems to have been designed for the purpose of reminding the audience of the fact that nothing is really going on behind the painted door of the set design, and that this world, about which they know everything there is to know, is indeed a fictional one. ${ }^{49}$ The play therefore confirms the classical concept of theatrical mimesis as a semiotic structure, which brackets the action in an as-if-dimension: ${ }^{50}$ here, theatrical representation clearly refers to something that is not really there, and requires the audience's ability to decode its signs. At the same time it is based, it seems, not so much on the idea of a Coleridgean "suspension of disbelief," but rather on a particularly heightened and continued disbelief - that is: on the "recognition of fiction as fiction," which not only adds yet another amusing, reflexive level of meaning to the theatrical event, but also allows for "insight purged of illusions." 51 The sex on stage evidences in this case that, on the audience's part, the play presumes - and generates -

49 The sex on stage in this case is obviously one of the instances where "the form winks at the content" and therefore becomes more visible as such (Bert O. States, Great Reckonings in Little Rooms. On the Phenomenology of Theater. Berkeley et al.: University of California Press, 1985, p. 32.

50 Even though this is not the place to discuss Platonic and Aristotelian concepts of mimesis in general - and theatrical mimesis in particular - it is probably safe to say that both assume mimetic representation to refer to, or "stand for," that which it represents: Plato's critique of mimesis in Politeia, Book 10, is based on the "distance" he sees between representation and the eternal true ideas (see Joachim Küpper. "Mimesis und Fiktion in Literatur, Bildender Kunst und Musik." Zeitschrift für Ästhetik und allgemeine Kunstwissenschaft, vol. 53, no. 2, 2008, pp. 169-190, p. 169, n. 2), but Plato nevertheless sees one as - ineptly or wrongly - referring to the other (see Arbogast Schmitt. "Mimesis bei Aristoteles und in den Poetikkommentaren der Renaissance.” Mimesis und Simulation, edited by Andreas Kablitz and Gerhard Neumann. Freiburg: Rombach, 1998, pp. 17-53, p. 27). According to Aristotle it is thanks to the referential structure that mimesis may be useful in processes of learning: theatrical and poetical mimesis can teach the characteristics of a person (be he/she fictional or historical), because it shows his/her actions in so far as they express this particular character (ibid., p. 37), and are understandable as its signs. As Schmitt demonstrates, Renaissance commentaries on Aristotelian poetics tend to shift the focus of the semiosis of theatrical representation towards the "natura ipsa" of world and humankind (see ibid. 45), that is: "good" representation is understood as a metonymic or metaphoric encryption of commonly human traits, vices, and actions. On the question of mimesis in connection with the "as-if"-dimension of fiction - which remains strangely unreflected in Aristotle - with respect to Augustine's Soliloquia, see Küpper, "Mimesis und Fiktion,” p. 172 f. On the 'sign-structure' of representation see ibid., p. 175, n. 17.

51 Rudolf Behrens. "Die Vorstellung des Eros. Imagination und Liebesgenese in der Literatur von Früher Neuzeit bis Romantik (Ficino, Du Plaisir, Marivaux, Foscolo).” Liebessemantik. Frühneuzeitliche Darstellungen von Liebe in Italien und Frankreich, edited by Kirsten Dickhaut. Wiesbaden: Harrassowitz, 2014, pp. 93-131, p. 100; my translation. 
a twofold knowledge about the representation on stage: a knowledge about the theatrical fiction that is superior to the perspectives of the fictional characters, and a reflective knowledge about its fictionality. And so, even as the play reaches the lieto fine with all its enlightening moments of recognition, its audience will still know more than its characters.

Even though it is beyond the purpose and reach of this paper to elaborate on the cultural-political meaning of the play as a theatrical reflection of the Medicean conquest of Roman space in their ascent to the papacy, ${ }^{52}$ or on its Boccaccian filiation, ${ }^{53}$ the very existence of both of these undeniable dimensions of its meaning may further enhance my point: watching the intricate play and following its political-allegorical as well as its intertextual references appears to be a pursuit focused very much on (self-)reflexive intellectual gratification.

Needless to say, this does not deny that the audience's phenomenal experience may not at the same time be characterized by a feeling of "togetherness" brought forth by the collective quality of the theatrical event, ${ }^{54}$ which may have even been enforced by their communal understanding of the play's semiotic sub-strata - by them all 'getting the joke.' Their understanding of the play itself, however, is a markedly representational knowledge with the fictional world as its object. ${ }^{55}$

52 R. L. Martinez. "Etruria Triumphant in Rome: Fables of the Medici Rule and Bibbiena's Calandra." Renaissance Drama, no. 37, 2010, pp. 69-98, see also Ferroni, “I due gemelli,” p. 33. 53 On Boccaccio's Decameron as pre- and/or subtext of the play, which has not only obviously influenced its content and the development of its characters but is present even on the linguistic / stylistic level of the comedy, see, with many references to further studies on this subject, Padoan, "Introduzione," p. $18 \mathrm{ff}$.

54 Gulizia, "Spatial Traffic,” p. 118.

55 With the drastic difference of social status between audience and characters in mind, I would go so far as to argue that the audience's "togetherness" depends to a great extent on their "apartness" from the play's characters: the audience form a community in so far as the characters constitute its "other" (see, with a slightly different focus, Gulizia, "Spatial Traffic," p. 118). Significantly, the play's surprisingly persistent preoccupation with physical experience, corporeality, and sensory perception, as has been compellingly described by Gulizia, is observable mostly in characters that clearly belong to the lower social classes (servants), or are marked by their lack of intellect (Calandro). Other characters use allusions to corporeality mostly for cruel mockery and ridicule, as in the whole sequence of Calandro's supposed transportation in a chest. 


\section{Henry V: everybody knows}

Of course, in the scene of "royal romance"56 at the end of the "warlike Harry['s]" (Prologue 5) military campaign, no one actually has sex on stage. Yet, motivated (if at all) by the scene's obvious and outspoken preoccupation with the issue of dynastic continuity, sex is continually evoked, alluded to, or hinted at. ${ }^{57}$

The history play, written somewhere in spring / early summer of 1599 as the third part of Shakespeare's so called "Henriad," continues the dynastic tale of its prequels by staging the military accomplishments of the second Lancastrian king. Not only does the rebellious prince Hal, who in the two parts of Henry IV was seen running wild in the taverns of Eastcheap, complete his transformation into a charismatic, yet sometimes cruel and cold-hearted leader. He also declares war on France under the pretence of a genealogical claim to the French throne, crosses the channel with a small army, conquers Harfleur, and virtually annihilates the French army in the famous Battle of Agincourt. This then gives him the right to claim the French princess's hand in marriage as well as a large number of dukedoms and the position of heir to the French throne. During the negotiations following his victory Henry declares the Princess to be his "capital demand” (V.2.95), and the French King Charles VI is in no position to object. Henry doesn't need to woo her. And yet he does.

It is almost annoyingly simple to describe what happens on stage: Henry sends his noble counsellors off to negotiate once more with the French king and his entourage, asks that Princess Catherine will be left behind with him, and then talks quite a lot. Her answers to his rhetorical endeavors consist mostly of "I cannot tell vat is dat," "I cannot tell," or "I don't know dat" (V.2.173; 189; 204). At some point Henry speaks equally basic French, a little later they kiss, and at that very moment (thanks to Shakespeare's impeccable sense of timing) King Charles and the whole group of French and English nobles return.

56 William Shakespeare. Henry V, edited by Gary Taylor, Oxford: Oxford University Press, 1982 (The Oxford Shakespeare), p. 28. References in brackets are to this edition.

57 V.2.198-202; V.2.205-208; with regard to the play's continued reference to the problem of dynastic continuity as well as questions of male fertility and sexual prowess, see Rebecca Ann Bach. "Tennis Balls: Henry $V$ and Testicular Masculinity, or, According to the $O E D$, Shakespeare Doesn't Have Any Balls.” Renaissance Drama, 30, 2001, 3-24. During the reign of Elizabeth I these matters evidently had a specific biopolitical background; see Marie Axton. The Queen's Two Bodies: Drama and the Elizabethan Succession. London: Royal Historical Society, 1977, $112 \mathrm{f}$. 
Complications arise, however, when it comes to describing how it happens. They start with Shakespeare's refutation of each and every one of the idealistic models of behavior Renaissance culture offered for this topical situation of courtship. From the outset Henry refers to the most elementary stereotypes of Renaissance discourses of love in their courtly, Petrarchist, and Neoplatonic varieties, only to refuse to follow any of their playbooks. ${ }^{58}$ And if the king's behavior frustrates expectations, then the princess's does, too. Instead of gracefully accepting the royal offer of marriage, her short evasive answers tease and stall Henry, who - for once in the entire play - seems to be completely out of his depth until, at long last, he does something he is charmingly incapable of: speaking French. In most productions this is the moment when the ice finally begins to melt. ${ }^{59}$ From this point onwards, Henry and Catherine start sharing a tone of playful self-deprecation. ${ }^{60}$ The complications continue, because little by little the colloquy turns into what I will call - for want of a better (or more historically correct) term - a flirt.

58 As far as I am aware, this has not been noted before. For an overview of the plural Renaissance concepts of love and their connected discourses I refer to Dickhaut, Liebessemantik; Klaus Hempfer. "Die Pluralisierung des erotischen Diskurses in der europäischen Lyrik des 16. und beginnenden 17. Jahrhunderts (Ariost, Ronsard, Shakespeare, Opitz)." GermanischRomanische Monatsschrift, 38, 1988, pp. 251-264; Amor sacro e profano. Modelle und Modellierungen der Liebe in Literatur und Malerei der italienischen Renaissance, edited by Jörn Steigerwald. Wiesbaden: Harrassowitz, 2012, and id. Amors Renaissance. Modellierungen himmlischer und irdischer Liebe in der Literatur des Cinquecento, Wiesbaden: Harrassowitz, 2014; with a particular focus on Shakespeare, see Jill Line. Shakespeare and the Ideal of Love. Rochester: Inner Tradition, 2004; Souls with Longing. Representations of Honor and Love in Shakespeare, edited by Bernard J. Dobski and Dustin A. Gish. Lanham: Lexington Books, 2011; and Stanley Wells. Shakespeare, Sex \& Love. Oxford: Oxford University Press, 2010. On the ironic details of this refusal of Renaissance discourses of love, in so far as they constitute contemporary knowledge about love, as well as its consequences for the play's contesting of Renaissance concepts of subjectivity, see E. Schomacher. "How to Rule, How to War, How to Love - and How to Act: Shakespeare's Henriad and Skills." Forthcoming.

59 See e.g. Dominic Dromgoole's production for Shakespeare's Globe, available on DVD as Shakespeare's Globe Henry V, Season 2012, Globe on Screen, 2012; the wooing scene starts at about 02:21:00 of the play. The same holds for Kenneth Branagh's film production Henry V, Renaissance Films PLC, 1989. A different - and, to my view, not entirely convincing - interpretation was developed in Thea Sharrock's production Henry V, The Hollow Crown, Part 3, BBC, 2012, where Henry's attempt at speaking French (as well as most of the scene's bawdiness) was cut.

60 See Henry V, V.2.179-185 or V.2.210-211; the change of mood is also reflected in the fact that from this part of the scene onwards Catherine is addressed as someone Henry is willing to let into his sphere of political power (see "England is thine, Ireland is thine, France is thine, and Henry Plantagenet is thine," V.2.230-231; or "We are the makers of manners," V.2.262), and is taken seriously as a political force herself (“queen of all," V.2.235). 
Critics have never ceased to point out that from a logical point of view this flirtatiousness is highly unconvincing: ${ }^{61}$ in addition to the much discussed language barrier, and the blatant political motivation of their marriage, Henry and his army have just done away with several members of Catherine's family. Actors and directors, however, feel that Shakespeare provided "the simplest answer" to the scene's apparent incongruity with the rest of the play, that is, the premise "that the two characters do literally in the course of one brief interview fall in love." ${ }^{62}$ Also, the multiple logical impediments to the characters' romantic attachment do not prevent audiences from enjoying the scene. ${ }^{63}$ Still today, audiences simply do not seem to watch whatever is happening between the king and the princess from a logical point of view.

I will try to show here that the reason why they do not so is because the scene, in a way, does not allow them to. In fact, I will try to show that the scene works so well on stage precisely because it succeeds in involving the audience on a physical-emotional level; it purposely, and skillfully, makes them share its flirtatious mood, rather than analyse its preconditions. It aims at a "corporeal grasp of something that eludes cognitive understanding."64 That way, the audience do not think of the reasons why King Henry V and Princess Catherine of Valois should or should not fall in love. Instead, they just fall in love with them. ${ }^{65}$ And I aim also to show that, in this case (as opposed to La Calandra), it is precisely this emotional sharing and taking part, as a form of non-referential and embodied knowledge, that the play as a whole requires and implements. Much like in La Calandra, then, the senseless, yet sensual scene is where the play's presuppositions concerning the audience's perceptive stance become most obvious and their implementation is taken to the extreme.

61 So much so that Hedrick even proposes to read the scene against its own text, in an admirable attempt to defend it against critical disapproval (see Hedrick, "Advantage, Affect, History,” p. 470; p. 478-480).

62 Kenneth Branagh. "Henry V." Players of Shakespeare 2. Further Essays in Shakespearean Performance by Players with the Royal Shakespeare Company, edited by Russell Jackson and Robert Smallwood. Cambridge et al.: Cambridge University Press, 1988, pp. 93-105, p. 104.

63 In Gary Taylor's words, "in the theatre" the scene is still "irresistible" (Henry V, p. 71); according to Michael Goldman any critical assessment of the scene should take this into account as a consciously produced theatrical effect: "The theatrical weight of the wooing scene in Henry $V$ [...] must be calculated on the assumption that the actor playing the King will try to generate the most pleasure allowed him by the lines and the events of the scene." (Goldman, The Energies of Drama, p. 8).

64 West, "Understanding in the Elizabethan Theatres," p. 125.

65 The intense reactions of the audience throughout the scene are perceivable even on the published DVD of Dominic Dromgoole's production of Henry $V$. 
I will suggest that the scene achieves the effect of drawing spectators into its emotional dynamics by using a combination of several scenographic and performative techniques; over the next few pages I will take a closer look at two of them. Sex does, in one way or another, play an important part in both: The first of these techniques consists of the pervasive presence, actually a kind of crescendo, of what Stanley Wells has dubbed "accumulatively lewd wordplay." 66 And the second one I would like to describe as an accentuation of the embodied aspects of acting, that is: an accentuation of the fact that what actors do is not just pretending.

The lewd wordplay, in this case, works in a similar way as in other Shakespearean scenes of sexual banter in comedies such as Much Ado About Nothing, As You Like It, Love's Labour's Lost, or The Twelfth Night, that is, by alluding to erotic and/or sexual connotations of words, figures of speech, or metaphors, while at the same time keeping their denotative meaning in play. In this way the sexual undertone is only ever insinuated or implied, and often remains intriguingly doubtful; its very perceptibility as such depends on the context and the hearer. Whether a specific figure of speech is understood as a "bawdy quibble" 67 strongly depends on whether there are others around it that are, and on the hearers' accumulating receptiveness to them. ${ }^{68}$ In these other cases of Shakespearean badinage, however, the allusions are usually addressed to another of the play's characters.

As Stephen Greenblatt has stressed, in these dialogues of "erotically charged sparring" language is "perfectly embodied": ${ }^{69}$ He argues that the dialogues function as a theatrical transformation of the "erotic heat" or "friction"70 that medical theories of Early Modernity assumed was necessary not only for conception and procreation, but also for the formation of the foetus's gender, and hence that they allow room for the characters' formation and acknowledgement of their own (sexual) identities. ${ }^{71}$ Characters do not express an

66 Wells, Shakespeare, Sex \& Love, p. 93.

67 Ibid., p. 148.

68 Stanley Wells rightly notes in this regard that "Shakespeare's language is polyphonic; rather as, in listening to music played on a keyboard, our ears may pick out a note of a melody while subordinating its harmonies in our consciousness, so in a passage of Shakespearean verse, though we may subconsciously acknowledge the possibility of a sexual undertone, that sense forms only a small part of our apprehension of what is said." (Ibid., p. 9)

69 Stephen Greenblatt. "Fiction and Friction." Shakespearean Negotiations. The Circulation of Social Energy in Renaissance England. Berkeley: University of California Press, 1988, pp. 6693, p. 89.

70 Ibid., p. 85.

71 Greenblatt sees the erotic wordplay in Shakespeare's plays as a theatrical appropriation of contemporary theories of procreation, and their concept of erotic heat: just as medical treatises 
"inward" emotional state - or even an individuality - that somehow existed prior to, and independently of, this "sparring." Instead they enact and share emotion with and through their bawdy exchanges. ${ }^{72}$

In the wooing scene of Henry $V$, though, the French princess does not speak English well enough to join in the game. This time the only possible addressee of the bawdiness is the audience - an audience, moreover, who have been prepared for this by the "English lesson" Catherine receives from her nurse in Scene III.4, where mispronounced English vocabulary ("gown," "foot") drifts over into French obscenities. ${ }^{73}$ It seems, therefore, the effects of the scene's erotic "dallying with words" 74 are aimed at the spectators: again, its bawdiness does not so much express something the spectators have to decode in order to know something about the scene or its characters, but rather brings forth a specific mood that the audience is invited to share. ${ }^{75}$ They are drawn towards a participatory mode of knowing, or being in sync with the characters, rather than interpreting them. Therefore, Henry's bawdiness deserves closer attention.

Examples abound, and they grow more and more drastic and explicit as the scene goes on, so that most modern productions avoid playing up to the many double-entendres: ${ }^{76}$ they range from Henry's insistent pleas that Catherine might "take" or "have" - rather than choose, accept, or simply marry -

argue that "[...] the generative power of nature centers on fruitful, pleasurable chafing” (ibid., p. 88), Shakespearean drama in particular turns this - in its verbalized form - into a means of the generation of characters and their individuality.

72 "[A]t moments [Shakespeare's] plays seem to imply that erotic friction originates in the wantonness of language [...]” (ibid., p. 89).

73 "Foot" in the Princess's ears obviously sounds similar to the French foutre, "gown," mispronounced by her nurse as "cown," is associated with the French con, cfr. III.4.46-51.

74 Greenblatt, "Fiction and Friction," p. 90.

75 The scene's use of language therefore provides an example of what Jan Söffner describes as "organic and tool-like infusion of language into a certain feel (Gespür) and action" (see Jan Söffner. Partizipation. Metapher, Mimesis, Musik - und die Kunst, Texte bewohnbar zu machen. Paderborn: Fink, 2014, p. 55; my translation). Greenblatt comes closest to observing this aspect of Shakespearean language, and in particular his "erotic sparring," in acknowledging that Shakespearean drama not only "uses" the "erotic power" of friction, but also "returns it with interest, as it were, to the audience" (Greenblatt, "Fiction and Friction," p. 88).

76 One reason for this may be that, for a modern audience at least, they sometimes border on "groan-jokes," those jokes "so obvious that the hearer may even feel a kind of comic resentment at being expected to find [them] funny" (Wells, Shakespeare, Sex \& Love, p. 90). Luckily though, for my purposes, Dominic Dromgoole's celebrated version for Shakespeare's Globe, London, in 2012 showed the scene with much of its sexual imagery intact, and I will occasionally refer to this production's way of staging it. 
him, ${ }^{77}$ to his jesting assertion that, if only methods of wooing were more suitable to his talents ("if I could win a Lady at leap frog"), he should "quickly leap into a wife” (V.2.138-139). ${ }^{78}$ Further examples of sexual wordplay include Henry's anticipation of Catherine's mocking comments about "those parts in me that you love with your heart" (V.2.194), or even - as a kind of reverse wordplay - his curiously coy translation of the French "baiser" as "to kiss" (V.2.255).

Their cumulative effect can probably be best described by comparing it to the perception of a rhythm or a melody: not only does it cause an interplay of what Husserl calls "retention" and "protention"; 79 that is, something like a reverberation of what has just been said, and its opposite, an anticipation of what will be said, ${ }^{80}$ which works on a physical, embodied level, bringing about a phenomenal presence of what is past and what is anticipated. ${ }^{81}$ The "accu-

77 For "take" see most prominently V.2.162-164: "If thou would have such a one, take me; and take me, take a soldier; take a soldier, take a king." For his uses of "have," see V.2.225; 236-237. With regard to other Shakespearean examples of the use of "take" in the sense of "have sexual intercourse with," see Wells, Shakespeare, Sex \& Love, p. 151.

78 In Dromgoole's production Jamie Parker as Henry sophisticatedly plays up to this sexual pun by turning it into a Freudian slip avant la lettre: he shows Henry react to his own line as if he realized its bawdy innuendo only after saying it; see Shakespeare's Globe Henry V, 02:28:00. This also goes to show that in performance sexual puns - even if spoken by a male character - need not appear chauvinistic.

79 Edmund Husserl. Texte zur Phänomenologie des inneren Zeitbewusstseins, edited by Rudolf Bernet. Hamburg: Meiner, 1985; see Francisco J. Varela. "The Specious Present: A Neurophenomonology of Time Consciousness." Naturalizing Phenomenology, edited by Jean Petitot. Stanford: Stanford University Press, 1999, pp. 266-314.

80 As Merleau-Ponty beautifully explained, the "perceptual field [...] draws along in its wake its own horizon of retentions, and bites into the future with its protentions." (Maurice MerleauPonty. Phenomenology of Perception. London et al.: Routledge, 1962, p. 416).

81 Bernhard Waldenfels's precise analysis of the connection of rhythm, perception, and embodiment has proved very enlightening in this regard: Bernhard Waldenfels. "Zeitverschiebung. Motive einer Phänomenologie der Zeiterfahrung." Zeit und Text. Philosophische, kulturanthropologische, literarhistorische und linguistische Beiträge, edited by Andreas Kablitz, Wulf Oesterreicher and Rainer Warning. Munich: Fink, 2003, pp. 33-45, where he describes rhythm as belonging to those Bewegungsgestalten ("figures of movement") that are "neither purely physical nor purely psychological"; their formation (Gestaltbildung), he states, takes place "between things and body and transgresses both" ("spielt sich zwischen Dingen und Leib ab und greift auf beide über [...].” p. 40; my translation). Much like the accumulating bawdiness, in rhythm the single elements are not identical but become identified as our experience keeps "coming back to them" (ibid., p. 40; my translation). For the importance of rhythm for the interpretation and performance of emotion in Shakespearean plays (though without reference to its perception by an audience), see Peter Groves. "My Heart Dances:' Performing Emotion through Shakespeare's Rhythms." Shakespeare and Emotions. Inheritances, Enactments, Legacies, edited by R. S. White. Basingstoke et al.: Palgrave Macmillan, 2015, pp. 83-94. 
mulatively lewd wordplay" also actively involves the listeners - in this case: the audience - in the process of perception: they cannot passively receive it, because it only exists as long as their own perception creates it and takes part in it. The first technique, therefore, causes a kind of transgression of the stage's boundaries on the audience's part: the spectators become part of the performance in so far as their active, embodied reception and complementation, as it were, becomes an integral constituent of the scene's emotional dynamics.

With the second technique the further blurring of the differences between theatrical representation on stage and the world of the audience in front of the stage originates in the stage business itself: when Henry and Catherine kiss at the end of their private conversation, the audience bears witness to a performance that is clearly not only make-believe. The stage kiss belongs to - and is probably the one of most intense examples of - a whole range of actions on stage that contest the classical paradigm of mimesis. As Renaissance drama and Shakespeare in particular - was well aware: stage business that relies on the actors' bodies questions the supposed separation and the referential structure between the as-if-world of theatrical fiction and its "signified," the "real" or phenomenal world, but also the one between actor and character: ${ }^{82} \mathrm{An}$ apple eaten on a stage is gone from the "real world," and is digested not by a fictional character; ${ }^{83}$ dances or fencing duels cannot be played on stage unless the actors are apt dancers or fencers in "real life." As Hamlet despairingly attests: tears shed on stage are not just a character's tears. ${ }^{84}$ And there simply is no way for actors to "represent" a kiss, except by really kissing. Significantly, the wooing scene culminates in a moment in which the action on stage is as real as actions in front of it. ${ }^{85}$

82 The boundaries and separations between make-believe and "real life" were perceived as (dangerously) permeable and precarious, as is shown by the anti-theatrical writers' fears of the effects of acting on the actors, but also by a number of medieval and early modern theater legends (see with respect to the first, Laura Levine. Men in Women's Clothing. Anti-Theatricality and Effeminization, 1579-1642, Cambridge: Cambridge University Press, 1994; with respect to the urban legends of the theater see Jody Enders. Death by Drama and other Medieval Urban Legends, Chicago: University of Chicago Press, 2005).

83 See ibid., p. 5.

84 I am, of course, referring to the famous Hecuba Soliloquy in II.2. of Shakespeare's Hamlet, especially Hamlet's attributing the tears to the actor (First Player), rather than the character: "What's Hecuba to him, or he to Hecuba, | That he should weep for her?" See the scene's reading with regard to the First Player's embodiment of emotion in John H. Astington. Actors and Acting in Shakespeare's Time. The Art of Stage Playing, Cambridge et al.: Cambridge University Press, 2010, p. 17.

85 It ends, as Enders puts it, with a moment that provokes questions about "where theatre ends and life begins" (see Enders, Death by Drama, p. 2). On the inseparability of representational mimesis and the dimension of embodiment in drama, see with respect to modern drama 
With this, the scene blurs even the most basic distinctions of theatrical representation - the one between audience and actors -, and dissolves the most elementary division of theatrical space - the one between auditorium and stage. ${ }^{86}$ With the audiences' embodied participation and the actors' embodied performing, theirs is the non-representational knowledge of a "shared space." 87

In this way the history play also aims at a mode of perception that tends to fade-out the issue of its fictionality. Of course, the play does fictionalize the historical events and characters it shows; it obviously appropriates them sometimes rather approximately - and it explicitly points to the fact that what the audience see on stage is not identical with what really happened during the historical Henry V's war in France. ${ }^{88}$ For the audience's emotional and physical taking-part, though, the difference between fiction and reality does not count for much: under the condition that the audience do contribute to the performance and work with the actors, the theater becomes the appropriate space of "bringing forth" the "warlike Harry, like himself" (Prologue 5).

Erika Fischer-Lichte. "Was verkörpert der Körper des Schauspielers?” Performativität und Medialität, edited by Sybille Krämer. Munich: Fink, 2004, pp. 141-162, and "Verkörperung/Embodiment. Zum Wandel einer alten theaterwissenschaftlichen in eine neue kulturwissenschaftliche Kategorie.” Verkörperung, edited by ead., Christian Horn and Matthias Warstat. Tübingen et al.: Francke, 2001, pp. 11-25.

86 West, "Understanding in the Elizabethan Theatres," p. $134 \mathrm{f}$.

87 The concept of "shared space" has been developed in phenomenological and cognitive research on gestures (see Matthew Ratcliffe. "The Structure of Interpersonal Experience." The Phenomenology of Embodied Subjectivity, edited by Rasmus Thybo Jensen and Dermot Morgan. Cham et al.: Springer, 2013, pp. 221-238); for an example of its usefulness in the description of aisthetic experiences see Esther Schomacher and Jan Söffner. "Warum es mit Repräsentationsformen nicht getan sein kann. Sieben Thesen zum Enactive Criticism.” Repräsentationsformen von Wissen. Beiträge zum XXVI. Forum Junge Romanistik in Bochum (26.-29. Mai 2010), edited by Eva Siebenborn, Annika Nickenig and Judith Kittler. Munich: Meidenbauer, 2011, pp. 125149, p. 132. As with the concept of "second-person interaction" developed by Shaun Gallagher and Dan Zahavi (see The Phenomenological Mind. An Introduction to Philosophy of Mind and Cognitive Sciences. London et al.: Routledge, 2008, p. 176), the emphasis is on an understanding independent of conscious analysis or "identification"; Gallagher's and Zahavi's concept refers to this kind of understanding with respect to other people's actions and feelings (that is, it is focused on the "problem of other minds", p. $184 \mathrm{ff}$.); whereas this is the attempt to describe a similar understanding with respect to works of literature, independent of a conscious construction of meaning or identification with the characters. For further elaboration see Söffner, Partizipation, chapter 1.4 “Sprache als Fertigkeit," pp. 68-79.

88 See Taylor's summary of the instances where Shakespeare departs from the historical sources and chronicles of his time, Henry V, p. $31 \mathrm{f}$. The play's Epilogue explicitly reminds the audience that its "bending author"'s (Epilogue 2) depiction of "mighty men" (Epilogue 3) was "mangling by starts the full course of their glory." (Epilogue 4). 


\section{Bodies, minds, and stages}

"The space of the stage and perception belong together," 89 Ulrike Haß summarizes the observation that stage architecture and design, and the practices of performance connected with them, reflect a culture's concepts concerning human perception. As it turns out, though, this is not so easily done, when in the culture in question several, sometimes contrary concepts concerning human perception are in circulation, and the issue of how human beings perceive, learn, and know is itself the cause of much disconcertment, but also excitement or even exhilaration. And Renaissance culture is, as Miranda Anderson has pointed out, such a case.

This means: Even if both plays - and particularly their senseless and sensual scenes - enforce, or implement, a certain way for the audience to know and understand, they do not simply affirm this knowledge; especially when they are seen in the context of their specific conditions of performance and their different stage architecture, it is obvious that they also (at least subliminally) contest it by counterpoising it to its respective other. If both plays can be said to reflect Renaissance concepts of human understanding, they also reflect their contrariety.

La Calandra's highlighting of the audience's referential, detached, visualanalytical "knowing-that" is obviously enabled - and even supplemented - by the conditions of performance provided by Italian court festivities (of which the performance of commedie erudite was a standard ingredient from the late fifteenth century on): ${ }^{90}$ The Serlian picture-stage with its elaborate, perspectivally constructed design showing an idealized version of the city where the comedy is set, the spectators seated in a closed-off auditorium, usually at some distance from its proscenium, in strict hierarchical order with the person of highest social rank sitting vis-à-vis the vanishing point of the said set design, the very marked difference of status between the aristocratic members of the audience and the characters on stage - all of this seems to second the perceptional observations developed from the striking example of III.10: ${ }^{91}$ the setting

89 Ulrike Haß. Das Drama des Sehens. Munich: Fink, 2006, p. 15; my translation.

90 Cesare Molinari. "Scenografia e spettacolo nelle poetiche del Cinquecento." Il Veltro, vol. 8, no. 6, 1964, pp. 885-902; Giovanni Attolini. Teatro e spettacolo nel Rinascimento. Rome et al.: Laterza, 1988, p. $42 \mathrm{ff}$.

91 See the collection of theories concerning theatrical architecture and stage design provided by Ferruccio Marotti. Storia documentaria del teatro italiano. Lo spettacolo dall'Umanesimo al Manierismo. Teoria e tecnica. Milan: Feltrinelli, 1974, as well as Pierre Francastel. Guardare il teatro. Bologna: Il Mulino, 1987; on the audience's position and perception in Italian Renaissance drama, see Cesare Molinari. "Les rapports entre la scène et les spectateurs." Le lieu théâtral à la Renaissance, edited by Jean Jacquot. Paris: Centre National de la Recherche Scien- 
contributes to providing the audience with "a complete view of the action from a masterful distance," 92 and in doing so shapes the audience's experience in accordance with emerging contemporary concepts of intellectual understanding and knowing, that is: humanism's growing epistemological confidence in visual perception and its mathematical/geometrical foundation, ${ }^{93}$ the privilege given to the visual sense as the one closely linked to the higher mental faculties of reason, and the (possibly even more growing) confidence in human capacities to learn and understand by deciphering, semiotic analysis, and reflection. 94

But yet, not only does the play itself contain elements that contradict this preference for visual-referential knowledge by displaying its vulnerability to deceit. ${ }^{95}$ More importantly the strict congruity of point of view and knowledge itself stresses the fact that, ultimately, any point of view, and therefore any understanding - even the audience's - is coincident with a physical, corporeal position; that is, the spectators' distanced, analytical, apparently non-corporeal understanding as such also hinges on a specific placement of their bodies within

tifique, 1968, pp.61-71, and "Gli spettatori e lo spazio scenico nel teatro del Cinquecento." Bolletino del Centro Internazionale di Studi di Architettura Andrea Palladio, no. 16, 1974, pp. 145-154.

92 Curiously, William West's synopsis of everything the Elizabethan theater is not provides a perfect description of the audience's position in Italian Renaissance drama, see West, "Understanding in the Elizabethan Theatres,” p. 136.

93 With the (re)discovery of linear perspective, the visual sense is - on the one hand - revalued as a mainly rational-mechanical device, even if - on the other hand - the very understanding of its functioning allows for the creation of enhanced illusionistic effects for the human eye (see Frank Büttner. "Rationalisierung der Mimesis. Anfänge der konstruierten Perspektive bei Brunelleschi und Alberti." Mimesis und Simulation, pp. 55-87, p. 63 ff. and p. 75). Connell particularly emphasizes the ambivalence in much of this epistemological reassessment of the human senses: "At issue was where the eye could legitimately be directed" (Connell, The Idolatrous Eye, p. 33).

94 See e.g. Connell's account of the "epistemological dialectic of image and word" (ibid., p. 5) in Renaissance England, in his Chapter 2: "Word Against Image: The Context of Iconoclasm," pp. 36-51. Connell repeatedly stresses the importance of a widespread printing culture as the medial-technological basis for this epistemological shift, as typography made "exact, unvarying texts possible and lent thereby an increased confidence to the 'word-in-space'." (Ibid., p. 29)

95 Most misunderstandings throughout the multi-layered intrigue of the play are, ultimately, optical illusions, while - especially during the virtuosic scenes of sexual cross- and un-crossdressing, of replacement of one twin by the other - it is often only the sense of touch, that is, the direct physical contact, that eventually proves the truth; see e.g. La Calandra, IV.2 or V.2. See in a similar vein the section 'Touching and Wearing' in Gulizia, "Spatial Traffic," p. 119121. 
the theatrical architecture. The audience's understanding seems disembodied, because it is based on their bodies' distance from the action onstage. In this way, their taking part in the experience of the court festivity and their sharing of courtly habits appear as a basic condition for them to be in the right position and develop the right perceptional stance towards the play. ${ }^{96}$ The audience's referential, semiotic understanding of the play, therefore, is by no means bodiless.

To come back to the comedy's senseless scene once more: Even as it exacerbates the audience's intellectual knowledge about the play's fictional world, its motive does emphasize, perhaps in a comically ironic way, the presence of bodies. After all, the scene is about sex.

In the case of Henry $V$ the contestation of the audience's knowledge - this time their embodied, embedded understanding - can be traced in the play itself. Even if Henry $V$ does, from its famous Prologue onwards, explicitly aim at the physical and emotional collaboration of the audience, it does so in a way that emphasizes the inseparability of embodied and intellectual understanding, and thereby constantly undercuts the modern distinction between mind and body.

Of course, the typical octagonal Elizabethan theaters - with their roofless center, where spectators paid one penny to watch the plays standing up, exposed to the elements, but in touching distance of the low and rather bare stage ${ }^{97}$ - "are arranged to resist" the "imaginary distance and control" associated with the picture stage. ${ }^{98}$ In Henry $V$ Shakespeare seems to have gone out of his way to highlight the participatory effects of this very setting as early as the Prologue: when the Prologue ironically and self-consciously reminds the audience that the theatrical venue (the "unworthy scaffold," "cock-pit," or "wooden 0 ," Prologue 10;11; 13) and the actors ("flat unraisèd spirits," Prologue 9) are the company's most reliable assets, ${ }^{99}$ he also alludes to the fact

96 In much the same way as Gulizia concludes from his close reading of the play's performance in Urbino within the context of elaborate intermezzi, the audience's attitude towards the play may be orientated less towards their "social domination," but rather towards the exploration of their "social skills"; see Gulizia, "Green Sense," in this volume.

97 See Andrew Gurr. The Shakespearean Stage, 1574-1642. Cambridge: Cambridge University Press, 1992; Henry S. Turner. The English Renaissance Stage: Geometry, Poetics and the Practical Spatial Arts, 1580-1630. Oxford: Oxford University Press, 2006.

98 West, "Understanding in the Elizabethan Theatres," p. 136.

99 With theatrical practice in mind, I assume that the Prologue is not - as it has sometimes been read (as e.g. in Melissa D. Aaron. "The Globe and Henry V as business document." Studies in English Literature 1500-1900, no. 40, 2000, 277-292) - sincerely apologetic. As Gary Taylor put it: "In practical terms, the modesty of the Chorus implies considerable confidence: in the theater, one apologizes only for one's most reliable effects, while expressing the greatest pos- 
that, if indeed the theater makes them take part in the performance, this is not the fault of its "physical limitations,"100 but actually their achievement. ${ }^{101}$

What is more: The Prologue, as well as several of the Chorus's other speeches, explicitly enjoin the audience to contribute to the project of "bring[ing] forth | so great an object" (Prologue $10 \mathrm{f}$.), turning the performance into a collective effort of actors and spectators. ${ }^{102}$ The recurring grammatical imperatives, however, consistently fuse what today would be seen as mental and physical efforts: "Let us [...] | on your imaginary forces work," the Prologue requests, only to invoke an active, equally physical employment of "thoughts" on the spectators' part: "Piece out our imperfections with your thoughts: | Into a thousand parts divide one man, | and make imaginary puissance." (Prologue 23-25), "'tis your thoughts that now must deck our kings" (Prologue 28); later on the Chorus exhorts the audience: "Work, work your thoughts" (III.0.25), and "eke out our performance with your mind." (III.0.35). The performance, it appears, is an effort that involves the audience's mental and physical faculties to the point where they become indistinguishable - "thoughts" can be "worked," "piece out," and "deck kings," imagination can provide "puissance," and a "mind” can "eke out."

sible confidence about anything wobbly." (Henry V, p. 56). For the interesting history of different critical readings of the Chorus, see Lawrence Danson. "Henry V: King, Chorus, and Critics." Shakespeare Quarterly, no. 34, 1983, pp. 27-43.

100 Goldman, The Energies of Drama, p. 59.

101 William West's brilliant description of this effect of Elizabethan stage architecture deserves to be quoted at length: "While the Elizabethan theater had no 'fourth wall' in the sense that the phrase came to have in the nineteenth century [...], it would be more accurate to say that the Elizabethan stage also lacked second and third walls (because it was on a thrust) and that the first wall was really a wall - not an imaginary barrier only [...]. Or perhaps it would be better to say that the Elizabethan theater did have a fourth wall, but one that encircled and included its audience. [...] [E]arly modern plays show the theater's whole circle, embracing both stage and pit, as set apart from the world outside it. Audience and actors have distinct parts, but are mutually permeable." (West, “Understanding in the Elizabethan Theatres,” p. 133.)

102 Dennis Kezar. "Shakespeare's guilt trip in Henry V." Modern Language Quarterly, no. 61, 2000, pp. 431-461, p. 435 f. even sees this as similar to religious ritual. Goldman, The Energies of Drama, p. $58 \mathrm{ff}$., emphasizes the analogies between Henry's speeches to his army and the Chorus's speeches to the audience: "All but one of the half-dozen famous speeches of the play have in common a concern for encouraging their hearers to make some kind of demanding effort, whether of action, feeling or imagination.” According to Goldman it is therefore no surprise if "the Chorus sounds very much like the King” (p. 59). This, however, puts the spectators in a situation very similar to the actors playing the soldiers. To further underscore this aspect of common effort and the audience's sharing in the performance, in Dromgoole's production the king's speeches are mostly spoken directly to the audience, who in these scenes are addressed as Henry's army, courtiers, etc.; see the most intense example, in Jamie Parker's version of “Once more upon the breach" (III.1.), at 00:47:35 of Dromgoole’s production. 
With this, Henry $V$ builds on Renaissance concepts of fluid, porous bodies, on notions of bodily receptiveness to others' feelings through the movement of "humors" and "passions" between bodies and their immediate environment, on notions of the "infectiousness" of moods, psychophysiological states, or feelings - as well as their status as a participatory kind of knowledge in its own right. ${ }^{103}$ But it also negotiates circulating theories about the social, physical, and embodied foundations of human cognition, ${ }^{104}$ that is: about the inseparability and interdependence of cognition and embodiment.

And to return once more to the play's senseless scene: For all its dependence on the audience's physical-emotional participation, the wooing scene also needs their semiotic understanding. Researchers noticed long ago that Henry $V$ is one of Shakespeare's most multilingual plays, ${ }^{105}$ and the English

103 As Anderson demonstrates with regard to a wide range of Renaissance writers, within the framework of Galenic anthropology world, body, and mind are mutually permeable; physical action and body states are perceived as interrelated with thought and imagination (see Anderson's summary, The Renaissance Extended Mind, p. 114 f.); West accordingly observes that “[...] certainly the sense [...] that thought might happen in detachment from physicality is a notion that is emergent rather than dominant in the period [...]" (West, "Understanding in the Elizabethan Theatres," p. 138).

104 On Renaissance theories of "humors" and "passions" as conceptualizing complex interrelations and interdependences between mind and body (rather than a clean-cut dualism), see especially: Noga Arikha. Passions and tempers: a history of the humours. New York: Ecco, 2007; Katherine Parks. "The Organic Soul.” The Cambridge History of Renaissance Philosophy, edited by Charles B. Schmitt. Cambridge: Cambridge University Press, 1988, pp. 464-484; Reading the Early Modern Passions: Essays in the Cultural History of Emotion, edited by Katherine Rowe, Gail Kern Paster and Mary Floyd-Wilson, Philadelphia: University of Pensylvania Press, 2004; Ulinka Rublack. "Fluxes: The Early Modern Body and the Emotions." History Workshop Journal, no. 53, 2002, pp. 1-16; with a special focus on Shakespearean works in this context see Ina Habermann. "Breathing Stones - Shakespeare and the Theatre of the Passions." ShakespeareJahrbuch, no. 140, 2004, pp. 11-27; David Hillman. "Homo Clausus at the Theater: Closing Bodies and Opening Theaters in Early Modern England." Rematerializing Shakespeare: Authority and Representation on the Early Modern English Stage, edited by Bryan Reynolds and William N. West, New York: Palgrave Macmillan, 2006, pp. 161-185; Arthur F. Kinney. Shakespeare and Cognition: Aristotle's Legacy and Shakespearean Drama. New York: Routledge, 2006; Gail Kern Paster, Humoring the Body. Emotions and the Shakespearean Stage. Chicago et al.: University of Chicago Press, 2004; Shakespeare and the Culture of Emotion, edited by Richard Meek (Shakespeare, no. 8, 2012, special issue); Gesa Stedman. "The Noblest Comment on the Human Heart': Shakespeare and the Theories of Emotion." Shakespeare-Jahrbuch, no. 140, 2004, pp. 115-129; Shakespeare and Emotions. Inheritances, Enactments, Legacies, edited by Robert S. White, Mark Houlahan and Katrina O’Loughlin. New York: Palgrave Macmillan, 2015.

105 Jean-Christophe Meyer. "The Ironies of Babel in Shakespeare's Henry V." Representing France and the French on the Early Modern English Stage, edited by id. Plainsboro: Associated Universities Press, 2008, pp. 127-142. 
king's wooing of the French princess makes linguistic difficulties one of the scene's central problems. ${ }^{106}$ Focusing entirely on the subject of national identity and difference (indicated by the lack of understanding) between the characters, researchers have noticed to a much lesser degree that - in order for the scene to work in an early modern playhouse - its London audience must have been expected to be capable of following the French dialogues, and, at least on a basic level, of translating back and forth between English and French. Otherwise the many jokes of linguistic interferences, or the humor of Henry's helpless attempts at speaking French, would have been lost. ${ }^{107}$ The audience's sharing in the flirtatious mood, therefore, is interrelated with their representational, semiotic interpretation of linguistic signs.

\section{As-if or not as-if? Theatrical answers to cultural questions}

This paper concerns two plays written in different languages, in different countries, belonging to different theatrical traditions and different genres, one at the beginning of the sixteenth century, one at its end. Still, as this paper set out to explore, apparently neither can avoid dealing with the same aisthetic and epistemic questions and concerns touching the theater; and even though neither provides explicit answers to those questions, they both do address them - particularly in their otherwise senseless scenes - by shaping the audience's perception, experience, and ultimately the ways of making the audience know and understand the action on stage. If dramatic production is necessarily located within the wider cultural net that surrounds and involves the theater, the aim of the paper has been to unravel some of its threads in the direction of circulating notions, and the connected anxieties and/or hopes, regarding human knowledge and sentience. In Early Modernity these issues seem to have found a particularly suitable outlet in the discourse surrounding the theater and its effects, whether it took the shape of an increased intellectual interest in poetics, or of an irreconcilable public controversy.

At first sight both plays seem to show no inclination for risk avoidance within the context of theatrical-epistemic debates. On the contrary, La Calan$d r a$ and Henry $V$ positively confirm the theater's enemies' most dreadful suspicions, undermining at the same time the strategies of its defenders: In addition

106 Downes, "French Feeling," p. 61.

107 Ibid., p. 59; p. 63. 
to the occasional lewdness of the play's texts, La Calandra exhibits a self-conscious fictionality of the theatrical world which, as anti-theatrical writers see it, as such not only enters into an unholy competition with God's creation, but also demonstrates its own "falsehood," frivolity, and intentional deceit. And even though it might seem that the perceptional stance it requires from - and enhances in - its audience, with its emphasis on the audience's intellectual understanding, was quite close to the one pictured by the theater's defenders by no stretch of the imagination does La Calandra provide the kind of edifying moral tale the apologists usually referred to in order to prove the theater's usefulness. And while the King's heroic deeds in Henry $V$ would indeed offer a lesson for audiences much to the taste of the theater's defenders - as Thomas Heywood's Apology for Actors actually confirms ${ }^{108}$ - Shakespeare's play explicitly does not aim at the audience's intellectual deciphering of a possible symbolic meaning, but exhorts the audiences' involvement on an emotional and physical level, and voluntarily sets out to affect them - just as the theater's enemies feared.

Yet, as a second glance reveals, the plays' implicit answers to the epistemic questions underlying the debate prove less purely provocative, but rather, in a complex way, conciliatory. Whereas the Renaissance theatrical discourse only allows for definite, clear-cut positions regarding the epistemic value of the stage - either it is perceived as a fictitious, as-if representation, and then audiences can learn from it by looking through the theatrical medium at its mediated message, or it is perceived as the immediate presence of sensual stimuli, whose representational, as-if dimension (its message) tends to be disregarded due to their inescapable corporeal infectiousness and attraction, and hence audiences can learn nothing - theatrical production itself obviously experiments with transitions and interstices: it can revalue embodied experience and interaction in the theater as a form of understanding, and extend the possibility of detached intellectual understanding to encompass its own mediality, but it can also obviously negotiate the interrelatedness, and interdependence of cognition and embodiment. With this, it brings the Renaissance's epistemic disconcertment, as it were, up against the theatrical debates' narrow trenches of as-if or not as-if.

108 "What English prince, should hee behold the true portrature of that famous King Edward the Third, foraging France, [...] and would not bee suddenly inflam'd with so royal a spectacle, being made apt and fit for the like atchievement. So of Henry the Fift; [...].” (Heywood, "An Apology,” p. 21). 